\title{
Study on the Integration Reform of Teaching and Research about the Situation and Policy Course in Chinese Colleges and Universities
}

\author{
Fan Chenxi \\ Zhuhai College of Jilin University \\ Zhuhai, P.R.China \\ baozihan_2006@qq.com
}

\begin{abstract}
Under the information technology environment in the Big Data era, it has changed significantly that the teaching requirements of Situation and Policy course in Chinese colleges and universities. Meanwhile, the particularity of Situation and Policy course determines that the traditional and single classroom teaching model has been unable to meet the requirements of contemporary education. We need to reform the teaching ideas, alter the traditional teaching conception and exert the advantages of information technology first. Then by constructing and utilizing network platform of teaching and research, we need to make the Internet Plus and Situation and Policy course to merge deeply and implement the integration reform of teaching and research so as to ensure teaching quality, improve teaching connotation, strengthen research ability and enhance capability of colleges and universities.
\end{abstract}

Keywords-Integration Reform, Teaching and Research, Situation and Policy, Teaching Reform, Big Data.

\section{INTRODUCTION}

The Situation and Policy course is one of the important parts of the Ideological and Political Theory courses in Chinese colleges and universities and they undertake the essential mission of ideological and political education for Chinese college students [1]. The course is the main channel to carry out the education of situation and policy for students [2] and it is ideological profoundly, political highly, realistic significantly and targeted strongly. In Big Data era, the environment of teaching has changes apparently.

In order to ensure the quality of teaching and learning and enable students to grasp the spirit of ideological and political education truly, we need to take into account various factors such as present conditions, existing problems, curricular syllabus, course content, educational model, teaching method, teaching team and instructional management. Above all, we need to attach great importance to scientific research, combine teaching and research tightly, and construct a scientific integration model of teaching and research for Situation and Policy course. Only in this way can we improve teaching connotation effectively, straighten curriculum system gradually, innovate teaching model scientifically, regulate teaching content properly, grasp new methods quickly, optimize teacher structure scientifically and standardize teaching management well.

\section{BACKGROUND ABOUT INTEGRATION REFORM OF TEACHING AND RESEARCH}

With the development of economy and technology, how to improve the quality of people's spiritual life has becoming the important research subject in the world. As a practical activity for training and cultivating people, the education of Ideological and Political can enrich people's spiritual world, enable people to enjoy the fruits of civilization and live a truly rich, substantial and happy life [3]. All the time, Chinese colleges and universities have been attaching importance to the teaching reform of Ideological and Political Theory courses. In recent years, a lot of manpower, material sources and financial sources have been put into the reform and it has achieved certain progresses and some success.

However, most of the Chinese colleges and universities are still in a traditional and conventional model, single classroom teaching. In addition, the construction of teaching stuff cannot keep up the pace of Big Data era. In this model, the teaching effect of Situation and Policy course depends on teacher's capability, qualification, enthusiasm, initiative and creativity. The updating of teaching content and knowledge is subject to teacher's learning and improvement, and this depends on whether teachers could follow the latest situation and requirements of the state closely, teacher's thinking is advanced, teacher's idea is clear and teacher's knowledge is novel or not. Besides, the teaching should be consistent and unanimous with the overall planning of Ideological and Political Theory courses, the whole curriculum setting of colleges and universities, and the cultivating schemes of students. So the quality of teaching is hard to be guaranteed, the teaching efficiency is low and the teaching effect is inconspicuous.

At present, the status of Situation and Policy course in Chinese colleges and universities is mainly reflected in the following three aspects.

Firstly, Situation and Policy course is diverse, flexible and time-sensitive, which decides that the teaching methods should be diversified, adaptable and up-to-date. But most Chinese colleges and universities currently still adopt single classroom teaching and hold the model of traditional knowledge inheritance and imitation. The majority of teachers of 
Ideological and Political Theory courses still take the 'indoctrination' education pattern for students as the only teaching way and students must passively accept ready-made book knowledge and formalist theoretical results, which are short of research and innovation [4]. Being lack of interaction, participation and creativeness, the broadcast teaching model brings about that the students are uninterested, negative and inefficient in learning. In fact, students in Big Data era need the personalized, autonomous and fragmented learning modal.

Secondly, some Chinese colleges and universities have not solved the problems of training and construction about teaching team for Situation and Policy course. The stuffing of teachers is expanding continuously, while the quality of teaching is declining constantly. Moreover, because of the heavy teaching tasks, the majority of teachers cannot update the latest requirements, contents and purpose of Situation and Policy course according to the official demands in time. Many teachers rush into teaching in class, repeat what the textbook or teaching material says and copy mechanically. In some colleges and universities, regular and professional teachers for Situation and Policy course are severely understaffed.

Thirdly, due to the lack of in-depth teaching research and scientific research for Situation and Policy course, it cannot be taken into account that not only campus culture, curriculum system, teaching objectives, educational scheme and regional characteristics about colleges and universities but also national policies and requirements, official demands and situations at home and abroad. In this case, the teaching model is not conductive to the unity of Knowledge-Attitude-Practice of students and cannot play the due role of Situation and Policy course.

To solve the above-mentioned problems, the reform of Situation and Policy course is imperative.

\section{GUIDING IDEOLOGY ABOUT INTEGRATION REFORM OF TEACHING AND RESEARCH}

Generally, the reform needs to renew the teaching idea in Big Data era, adopt the new teaching methods by constructing and utilizing network platform of teaching and research, establish the teaching model under the dual parallel paths from online to offline and form the teaching model with the multiple combinations of classroom teaching, network courses, expert lectures and scientific research. And it is called the integration reform of teaching and research about the Situation and Policy course for short. Specifically, the guiding ideology about the integration reform of teaching and research mainly includes the following four aspects.

\section{A. Obey the rules}

The prerequisite to implement the integration reform is that we must obey the official rules or regulations such as state policies, national requirements and official demands. Every country has its own laws, rules, features and habits etc. Therefore there are different teaching rules or regulations in different countries. In China, the reform must obey the rules or regulations of the Chinese Propaganda Department and the Chinese Ministry of Education. Based on that, the reform is adapted to local conditions, implemented flexibly and developed creatively.

\section{B. Make everyone be satisfied}

All these aspects need to be considered in the integration reform that characteristic of students, interests of teachers and development goals and requirements of colleges and universities. In order to implement the integration reform successfully, everyone who relates to it should be satisfied and happy. The integration reform should make students learn easily, happily and with fun, make teachers teach effortlessly, do research expediently and increase in income appropriately, and help colleges and universities optimize teacher structure, improve teaching level, enhance overall capability, strengthen external influence, build harmonious campus and save social resources.

\section{Begin from a high starting point}

By constructing and utilizing network platform of teaching and research, the integration reform begins from a high starting point. We should be good at importing and using the basic teaching resources with high quality from third parties, and utilizing the existing research results and achievements. We do not have to start all over again for the integration reform. Based on a certain basis and combined with the actual situation, we should find a new reform road to integrate teaching and research, benefit both teachers and students, and help colleges and universities develop sustainably.

\section{Be bold to innovate}

To change is to find new chance, and to challenge is to create new success. To be bold to innovate is that we should optimize the first type of teaching model, the classroom teaching model, and create the second type of teaching model, the integrated educational model based on the network platform of teaching and research. Optimizing the classroom teaching model is to construct and utilize the network platform of teaching and research, break the single traditional face-toface teaching model completely and change the conventional teaching and learning model thoroughly. Creating the integrated educational model is to combine education with scientific research in daily teaching, cultivating students and improving teachers' ability indeed.

\section{IMPLEMENTATION SCHEME ABOUT INTEGRATION REFORM OF TEACHING AND RESEARCH}

As an important carrier of information communication and economic exchange, the emergence of the Internet undoubtedly broke the existing pattern of education and teaching. How to face and use Internet has become a new developing trend of the education reform in colleges and universities. In view of the problems in the current Ideological and Political education, we need to make use of the advantages of Internet [5]. Therefore, in order to carry out the integration reform of teaching and research, we need to make a thorough implementation scheme based on taking full advantage of Internet.

The core component of the scheme is the network platform of teaching and research which can provide the services of 
online learning and teaching, full range of teaching and scientific research, providing the latest information and updating knowledge systematically. Not only can this effectively solve problems and create considerable economic benefits, but also produce social benefits and enhance the external influence for colleges and universities in a certain extent. The scheme to implement the integration reform contains the following five steps.

The first is to build the network platform of teaching and research. We need to build a network platform with the external cooperation, import the latest materials, information, textbook and monograph of the course, integrate the best teaching resources and provide all the above to students and teachers. This can improve their identity sense of course and enhance the viscosity of course.

The second is to reconstruct the curriculum structure. We need to establish gradually the full range of integrated teaching and research environment through constructing the open autonomous learning model through network platform of learning, employing well-known course experts and scholars to hold seminars, and encouraging students to participate in all kinds of scientific research, social practice and professional forum.

The third is to make innovation for the teaching forms. We can carry out a variety of activities such as debating competition, speech contest and essay contest. And we can also set up scientific research group. Students can independently establish research team according to special course topics, certainly assist teachers to bigger research which provided by the teachers, colleges, companies or professional institutions. This can improve the students' scientific research ability and team spirit greatly.

The fourth is to achieve and accumulate the research results. Through the above integration reform of teaching and research, we can achieve a lot of research achievements which include learning notes, teaching experience, research articles, academic papers, scientific reports and all kinds of electronic data and valuable information. We need to accumulate them comprehensively and study them deeply.

The last is to find the new problems, figure out the possible reasons and carry out a new and deeper integrated reform. A good, feasible and successful implementation scheme of reform should be a closed loop. That is to say, the each layer or step of the scheme serve the later and most of all the last must give results, experience and feedback to the first so that we can optimize the reform and make progress continuously.

\section{SUMMARY}

The flexible Situation and Policy course is widely involved in a wide range of fields, covers a variety of subjects and contains dynamic content. And it is highly concerned by the college students, and closely linked between students thought and social reality [6]. Now we are facing the Big Data era, and we are ushering the new trends of Internet Plus. We should make full use of information technology and the Internet, and combine the Internet and the integration reform of teaching and research about the Situation and Policy course in colleges and universities deeply. Through innovating the teaching and research model and invigorating the teaching and learning, we can solve the new problems in the development of colleges and universities. In this way, we can achieve the goals of autonomic learning and creative teaching, and adapt to the new requirements of higher education in Big Data era.

\section{ACKNOWLEDGEMENT}

This research was financially supported by the 2014 Hong Kong and Macao Research Project Fund from the Chinese Association of Hong Kong and Macao Studies (Grant No. HKM1407), the 2014 Work Innovation Project Fund on the subject of Ideological and Political Education from the Dep. of Guangdong Education (Grant No. 2014ZK003) and the 2015 Innovation Project Fund on Social Science of Zhuhai College of Jilin University (Grant NO.2015KYSKXJ037).

\section{REFERENCES}

[1] Zhao Jing-dong, The analysis on teaching reform of course Situation and Policy in newly-built university, Journal of Qiqihar Junior Teacher's College, General. No. 139, pp. 138-140, 2014. (in Chinese)

[2] Zhao Chang-geng, Research on the teaching practice of Situation and Policy course in colleges and universities, Northwest Medical Education, No. 6, vol. 16, pp. 1217-1218, 1224, 2008. (in Chinese)

[3] LIAO Xiao-qin, Pay Attention to Ideological and Political Education to Improve People's Quality of Spiritual Life, Journal of Sichuan Teachers College (Social Science), No. 4, pp. 30-33, 2005. (in Chinese)

[4] TANG Zhen-lin, On the Teaching Reform of Ideological and Political Education in Colleges and Universities, Education and Vocation, No. 24, pp.58-59, 2010. (in Chinese)

[5] SI Qin-tu, New Measures of Education and Teaching Reform of Ideological and Political in Colleges and Universities under the Background of Internet, Teacher, No. 2, P.55, 2015. (in Chinese)

[6] Zhang Jun, The innovation and practice of the teaching model of Situation and Policy course under the background of Internet Plus: Taking Nanning Vocational College of Information Technology as an example, Xue Yuan, No.28, pp. 39-40, 2008. (in Chinese) 